Uniwersytet Opolski

Wydział Filologiczny

Katedra Języków Słowiańskich

tel.: +48787340044

e-mail: agadomski@uni.opole.pl

ORCID ID: https://orcid.org/0000-0003-4274-0966

\title{
Персуазия, манипуляция и религиозный язык: теоретический аспект
}

Ключевые слова: теолингвистика, религиозный язык, речевое воздействие, персуазия, манипуляция

Littera docet, littera nocet.

В последние годы в связи с развитием, совершенствованием и общедоступностью каналов передачи и обмена информацией стали активно изучаться проблемы ее восприятия и воздействия на адресата. Безусловно, каждый акт коммуникации имеет свою цель и каждый адресант стремясь к ее достигнуть, действует таким образом, чтобы она поступала к адресату в неизменном виде и приносила ожидаемые результаты. По этой причине в центре внимания оказались персуазия, манипуляция, речевое воздействие и ряд других связанных с ними явлений. Современные исследователи рассматривают их в различных аспектах: начиная с психологических [Hovland 1953; Petty 1986; Chaiken 1986 и др.] и заканчивая языковыми [Голоднов 2003; Гончарова 2003; Чернявская 2014; Hoffmann 1996; Kosta 1996; Mann 1999; Moilanen 1996 и др.]. В данной ситуации нас прежде всего интересует языковая сторона вопроса.

\section{1. Персуазия и манипуляция как формы речевого воздействия}

Динамичное развитие теолингвистики на протяжении последних десятилетий привело к тому, что возникла необходимость взглянуть 
по-новому на целый ряд, казалось бы уже изученных и описанных явлений, в числе которых могут быть названы персуазия, манипуляция и речевое воздействие. Анализировать и описывать их вне связи друг с другом достаточно непросто, поскольку значения перечисленных терминов объединены такими общими семантическими компонентами, как 'влияние', 'воздействие', 'достижение цели' и другими, что достаточно часто приводит к смешению понятий и не всегда позволяет квалифицировать их должным образом. Считаем, что назрела необходимость взглянуть на данные явления с теолингвистических позиций и уделить в данном контексте особое внимание религиозному языку, который является их средством, инструментом, орудием.

Поэтому целью настоящей работы является исследование и описание персуазии, манипуляции, речевого воздействия, а также анализ религиозного языка, который в различных ситуациях может использоваться не только с целью формирования истинной, адекватной религиозной картины мира, но и быть инструментом различного рода манипуляций.

Обратимся к терминам. По мнению Т. Левандовски, в самом общем смысле термин „персуазивность” означает процесс или метод воздействия на человека согласно определённому мнению, позиции или действиям с помощью вербальных средств [Lewandowski 1994, 790].

Известно, что слово „персуазивность” (лат. persuasio, англ. persuasion, нем. Persuasion - „убеждение”, „уговаривание”) вошло в научный обиход лингвистики относительно давно. Данное явление изучалось ранее в рамках стилистики, лингвистики текста, психолингвистики, когнитивной лингвистики, теории речевого воздействия, теории аргументации [Голоднов 2003; Гончарова 2003; Иссерс 2009; Чернявская 2014; Hoffmann 1996; Kosta 1996; Mann 1999; Moilanen 1996; Sandig 1996 и др.].

Современные языковеды рассматривают персуазивность, персуазивную коммуникацию и стратегии персуазивности на материале различных видов дискурса [...]. Подобное разнообразие видов дискурса, представляющих интерес для лингвистов, исследующих феномен персуазивности, говорит о том, что данный феномен актуален для различных типов коммуникации [Хутыз, Колчевская 2018, 391-394], в том числе и религиозной.

И хотя традиционно явление персуазии воспринимается положительно, мнения ученых по данному вопросу не всегда совпадают: одна группа авторов рассматривает его как убеждающую (не принуждающую, не насильственную) коммуникацию, речевое воздействие, предполагающее попытку добиться результата ненасильственным путем 
[Чернявская 2014; Lewandowski 1994, 790; Zdunkiewicz 1991, 149 и др.]; другая считает, что в зависимости от ситуации оно может иметь и негативные последствия, поскольку представляет собой разновидность манипуляции [Голоднов 2003, 15; Шелестюк 2008, 170-175; Gansel 2011, 99; Bralczyk 2002, 75; Zdunkiewicz 1991, 149 и др.].

Как справедливо замечает Д. Здункевич-Едынак, „использование языка с целью оказания влияния на убеждения и поведение адресата неразрывно связано с вербальной коммуникацией (...). Создается впечатление, что мы редко говорим, имея в виду нейтральные разговоры об окружающей действительности. Мы часто используем язык только для того, чтобы убедить кого-то сделать что-то" [Zdunkiewicz 1991, 149].

А.В. Голоднов определяет персуазивную коммуникацию как исторически сложившуюся, закрепленную в общественной и коммуникативной практике особую форму ментально-речевого взаимодействия индивидов, осуществляемую на базе определенных типов текста и реализующую попытку речевого воздействия одного из коммуникантов (адресанта) на установку своего коммуникативного партнера/партнеров (реципиента/аудитории) с целью ненасильственным путем (посредством коммуникативных стратегий убеждения и „обольщения”) добиться от него принятия решения о необходимости, желательности либо возможности совершения/отказа от совершения определенного посткоммуникативного действия в интересах адресанта.

Для персуазивного воздействия характерны убеждение, направленное на принятие реципиентом рациональной аргументации адресанта; уговаривание, усиливающее рациональную аргументацию и воздействующее на рациональную сферу реципиента [Голоднов 2003, 15].

Ситуативно данный термин может приобретать и негативный оттенок, так как одноименный концепт отсылает нас к понятию манипуляции, а также использованию определённых языковых средств с целью влияния на мнение и поведение реципиента, хотя, по мнению учёных, негативная направленность термина „персуазивность” остается под вопросом [Gansel 2011, 99].

В.В. Шелестюк утверждает, что „персуазивность” представляет собой разновидность манипулирования, совокупность способов усиления рационального аргументирования [Шелестюк 2008, 170-175].

В. Е. Чернявская под манипулированием понимает „одну из форм речевого воздействия, нацеленную на то, чтобы вызвать определенное отношение/действие адресата именно в интересах отправителя сообщения, не обязательно совпадающих с интересами адресата. При 
этом адресат часто не распознает эту коммуникативную установку на управление его поведением или мнением" [Чернявская 2014, 28].

Д. Здункевич-Едынак считает, что термин „персуазия” сегодня перегружен негативными коннотациями. Данное явление связывают с тяжким грехом манипуляции - нечестного, потому что скрытого, управления мыслями, поведением и действиями реципиента [Zdunkiewicz 1991, 149].

Подобного мнения придерживается С. Баранчак, считающий, что „персуазивная функция - это своего рода конъюнктивная функция, которая проявляется не столько во всех возможных факторах выражения, задачей которых является обращение к реципиенту, а скорее в тех конкретных факторах, которые детерминируют или пытаются детерминировать его поведение (ментальное или физическое), детерминировать опосредованным, несколько скрытым образом, а не путем прямых запретов или распоряжений" [Barańczak 1983: 30].

Д. Здункевич-Едынак предлагает принять для дальнейшего рассмотрения определение Е. Бральчика, согласно которому, персуазивными являются только те элементы текста, которые служат „прямому и косвенному стимулированию отношений - состояний убеждений" [Bralczyk 2002, 75].

О речевом воздействии, по мнению А.В. Голоднова, можно говорить как о понятии, близком не только к понятию персуазии, но и к понятию манипуляции [Голоднов 2003, 15].

Таким образом, можно сделать вывод о том, что „в чистом виде” персуазия и манипуляция представляют собой „разнозарядные” формы речевого воздействия: если персуазия - это речевое воздействие со знаком „+”, использующее отрытые механизмы с целью достижения результата и предполагающее осознанный выбор адресата, то манипуляция - это речевое воздействие со знаком „,-", использующее скрытые механизмы с целью достижения результата, не обязательно совпадающего с интересами адресата. Язык во всем многообразии вариантов может служить своеобразным орудием, средством, инструментом описываемых процессов.

\section{2. Религиозный язык как средство манипуляции и персуазии}

Деятельность Церкви, как правило, связана с персуазией (убеждением), поскольку одной из ее основных задач является выработка соответствующего мировоззрения у ее последователей, сторонников, 
приверженцев. С целью воздействия на верующих (потенциальных верующих) и формирования соответствующей картины мира религии: языковой (наивной в случае работы с рядовыми мирянами) и концептуальной (более полной, научной, в случае работы со специалистами в области наук о религии) используется вариант языка, который в научной литературе принято называть религиозным языком.

Поскольку мир религии не однороден, многообразны и языковые средства, используемые для его описания. Это позволяет ученым говорить о религиозном языке в узком и широком понимании [Bajerowa, Puzynina 2000, 19-20], о его ядерной и периферийной зонах [Гадомский 2006, 186-193].

По мнению И. Баеровой и Я. Пузынины, „в более узком значении религиозный язык - это язык моральной и догматической теологии, а также язык ритуальный (литургический язык в христианстве), язык личных молитв, священных текстов (Библия), проповедей, произведений религиозной художественной литературы.

В более широком значении религиозный язык - это также разговорный язык, содержащий высказывания о Боге и отношении людей к Богу, а также язык текстов на религиозную тему - например, текстов по истории, социологии и психологии религии" [Bajerowa, Puzynina 2000, 19-20]. Хотелось бы также добавить, что в этом ряду могут быть перечислены и публицистические тексты, и произведения художественной литературы.

Как отмечают исследователи, „в религиозном языке отражается собственная картина мира. Через его содержание и структуру, через содержательные речевые акты и выбор лексических и стилистических средств конкретные высказывания обнаруживают актуальную картину Земного и Небесного. Самыми важными компонентами этой картины являются концепты Бога, Церкви, человека и отношений между ними, а также концепты жизни, времени, греха, души, рая и ада" [Greule, Kucharska-Dreiß, Makuchowska 2005, 73-91].

Рассуждая о религиозном языке как инструменте речевого воздействия, используемого с целью формирования религиозной картины мира или средства манипуляции, не следует забывать о теонемах - единицах служащих для передачи религиозного содержания и представленных на всех его уровнях. В индивидуальной речи, в контекстах, последние, сохраняя форму, могут приобретать иное, нерелигиозное, значение. Элементы светского языка также могут трансформироваться в теонемы при условии их использования в качестве средства формирования религиозной картины мира. 
Говоря же о „центре (ядре)” религиозного языка, следует иметь в виду прежде всего религиозный язык в узком понимании данного термина. Если же речь идет о его „периферии”, то здесь уместнее говорить о религиозном языке в широком понимании.

У анализируемого варианта языка очень богатые возможности, подтверждением которых являются его многочисленные функции, подробно описанные польским исследователем П. Кладочным.

1. Познавательная функция - классификация, дифференциация мира сверхъестественного и укрепление познавательного опыта.

2. Сакральная функция - обеспечение контакта человека с миром sacrum, функция молитв, литургий и других текстов.

3. Аккумулятивная (культуросозидательная) функция - сбор в системе языка и его подсистемах информации о действительности, об общественном опыте и передачу будущим поколениям знаний, культурных традиций, системы ценностей, моральных норм и т.д.

4. Социализирующая функция - объединение членов конкретных религиозных групп.

5. Анамнезирующая функция - обращение в настоящее время к памяти о „начале”. Реализуется в мифах и религиозных повествованиях.

6. Инструментальная функция - использование языка как средства для достижения определенных целей.

7. Эвокативная функция - вызывание у слушающего определенного отношения и эмоций.

8. Экспрессивная функция - самовыражение, проявление собственных эмоций, переживаний.

9. Импрессивная функция - обращение к слушающему с просьбами, призывами о выполнении определенных действий.

10. Метаязыковая функция - использование языка для описания религиозных высказываний.

11. Интеррогативная функция - оценочная, ценностная.

12. Регулятивная функция - запись прав, обязывающих верующих выполнять определенные действия.

13. Синергичная функция - взаимодействие в достижении понимания.

14. Перформативная функция - использование новой действительности в сакраментальных актах.

15. Поэтическая функция - более глубокое познание, открывание мира [Kładoczny 2004: 25-30].

Хотелось бы прежде всего обратить особое внимание на инструментальную и импрессивную функции, поскольку использование фор- 
мы и содержания религиозного языка в различных ситуациях и контекстах открывает неограниченные возможности для речевого воздействия (манипуляции и персуазии).

Одни и те же языковые знаки и формы, тексты различных жанров могут быть как средством персуазии, передачи религиозного содержания представителями классических религий, так и средством манипуляции сознанием, осуществляемой последователями различных лжеучений, религиозных ответвлений, течений, сект. Вследствие чего возникает возможность наблюдать диаметрально противоположные явления: с одной стороны, это могут быть классическая религия и вера в Бога, а с другой - сектантство, религиозный фанатизм, экстремизм на религиозной почве.

Во всех этих процессах принимают участие не только служители религиозного культа и верующие, но и представители других слоев общества, которые могут использовать богатый арсенал религиозного языка в благих и корыстных целях. Как отмечает Е. Бральчик, „при всех своих преимуществах в персуазийной деятельности у языка есть один существенный недостаток, обусловленный его преимуществами: язык дает возможность легко обманывать, о чем адресант очень хорошо осведомлен. Мы знаем, что можно обманывать при помощи звука, изображения, можно обманывать, воздействуя на такие „невинные” органы чувств, как обоняние и вкус, но реципиент редко понимает это. Язык - это естественная символическая система, система знаков, выполняющая роль посредника между нами и действительностью" [Bralczyk 2004, 10].

Именно поэтому в свое время „отец теолингвистики” Ж.-П. ван Ноппен обращал внимание ученых на необходимость создания такого раздела теолингвистики, как „критическая теолингвистика”, которая ,должна выяснять, употреблялся (употребляется) ли религиозный язык и каким образом, что очень важно, нерелигиозной идеологией, и, если это имеет или имело место, давать критику вырывания религиозного дискурса из его первоначального контекста" [J.-P. van Noppen 1996; цит. по: Kucharska-Dreiß 2004, 29].

Ярким примером употребления религиозного языка в корыстных, манипулятивных целях может служить идеология новой власти, лингвистическая программа, проводимая после Октябрьской революции 1917 года. Одно из ее первых постановлений было опубликовано в форме декрета „Об отделении иеркви от государства” от 20 января (2 февраля) 1918 года, вступившего в силу 23 января (5 февраля) того же года, задачей которого было переподчинение народных масс, 
при старой власти находившихся в постоянном контакте с Церковью. И здесь нелишне вспомнить И.В. Сталина, который, как известно, имел богословское образование и мог профессионально оперировать, богословской терминологией, понятиями, концептами. Поэтому новая официальная идеология, отказавшаяся официально от Бога, Веры и Церкви, пытаясь построить „свою иерковь”, создать „свою веру” и дать народу „своего бога”, не только не отказалась от религиозного языка, но и постаралась использовать его форму для управления и манипулирования народными массами, которые в основном были верующими православными. Именно в это время в языке новой власти появились такие выражения, как „священная война”, „священный бой”, „апостольг революиии” и т.п.

Новым руководством была проведена и реформа дореволюционной русской орфографии, используемой ранее при написании религиозных текстов. Официально реформа была задумана еще до 1917 года и объявлена 11 (24) мая 1917 года в виде «Постановлений совещания по вопросу об упрощении русского правописания» [Постановленія совьщанія 2017, 1-8], а 17 (30) мая на основании указанных материалов Министерство народного просвещения Временного правительства предписало попечителям округов немедленно провести реформу русского правописания; ещё один циркуляр вышел 22 июня (5 июля).

Была также объявлена борьба с неграмотностью - ликбез. Исторически термин „ликбез” возник как сокращение названия государственной программы Советской России по „ликвидации безграмотности”, начало которой положил декрет Совета народных комиссаров РСФСР „О ликвидации безграмотности в РСФСР” от 26 декабря 1919 года. Согласно данному декрету, всё население Советской России в возрасте от 8 до 50 лет, не умевшее читать или писать, было обязано учиться грамоте на родном или на русском языке (по желанию). Народному комиссариату просвещения предоставлялось право привлекать всех грамотных лиц к обучению неграмотных на основе трудовой повинности. Документ предусматривал также создание школ для переростков, школ при детских домах, колониях и прочих учреждениях, входивших в систему Главсоцвоса.

Людей стали обучать чтению новых текстов, написанных по-новому: простой, неграмотный, малограмотный народ, совсем недавно и на скорую руку обученный азам чтения и письма, часто полуграмотными учителями, сам того не понимая, оказался оторванным от письменных исторических памятников, от религиозных текстов и попал в совершенно иную концептосферу. Таким образом была прервана многовековая 
традиция. Естественно, что образованную часть населения не могла устраивать такая постановка вопроса.

Как отмечает М.В. Панов, „необыкновенно ярко отразила „языковую смуту" 20-х годов художественная литература. Речевые контрасты были использованы с целями экспрессивно-художественными, они соответствовали идейно-образным противопоставлениям в произведении" [Панов 1968]. В качестве примера приведем фрагменты из поэмы А. Блока „Двенадиать”.

1

А вон и долгополый -

Сторонкой - за сугроб...

Что нынче невеселый,

Товарищ поп?

Помнишь, как бывало

Брюхом шел вперед,

И крестом сияло

Брюхо на народ? (...)

2

Свобода, свобода,

Эх, эх, без креста! (...)

Товарищ, винтовку держи, не трусь!

Пальнем-ка пулей в Святую Русь (...)

3

Мы на горе всем буржуям

Мировой пожар раздуем,

Мировой пожар в крови

Господи, благослови!

11

... И идут без имени святого

Все двенадцать - вдаль.

Ко всему готовы,

Ничего не жаль... (...)

12

...Так идут державным шагом -

Позади - голодный пес,

Впереди - с кровавым флагом,

И за вьюгой невидим,

И от пули невредим,

Нежной поступью надвьюжной,

Снежной россыпью жемчужной,

В белом венчике из роз -

Впереди - Исус Христос.

[Блок 1999, т. 5] 
На примере данного текста очень чётко прослеживаются изменения, происходящие в обществе, общественном сознании и в языке: с одной стороны, на фоне всеобщего беспорядка, или нового порядка, - библейские персонажи ( „Исус Христос”), церковная символика („И крестом сияло / Брюхо на народ”), священнослужители („долгополый”, „Товарищ non”), а с другой стороны - помещение их в ситуацию, когда Бог должен благословлять ( „Господи, благослови!”) на разжигание „мирового пожара в крови”, народ должен „палить в Святую Русь”, да и сам Иисус Христос идет „В белом венчике из роз” и „Впереди с кровавыл флагом".

Все эти изменения нужно было возводить в норму и как-то фиксировать. Поэтому формирование нового русского языка в послереволюционную эпоху потребовало создания новых словарей, учебников, справочников, энциклопедий. Особое внимание отводилось лексикографической деятельности в связи с появлением новых номинаций, закрепляющих нововведения советского строя. Создание русских словарей было одной из главных задач советского языкознания, так как они должны были способствовать развитию нового общества, пополнению знаний, стать ключом к богатствам русского языка, а также являлись опорой при составлении двуязычных словарей для народов советского государства.

В 1920 году на правительственном уровне начали осуществляться мероприятия по создание словарей нового поколения. 18 января 1920 года В.И. Ленин в письме А.В. Луначарскому, признавая величие «Толкового словаря живого великорусского языка» В.И. Даля, отмечал, что этот словарь диалектный, поэтому необходимо создать новый словарь - классического русского языка. В результате в 1935 году был издан „Толковый словарь русского языка” в 4 т. под ред. Д.Н. Ушакова [Иглаева 2014, 95].

Как отмечает В.В. Шмелькова, „активно и сознательно проводимые в советское время атеистические мероприятия наложили запрет на лексику религиозную и церковную. Толковые словари середины XX века обязаны были подчеркнуть несовременность, „пережиточность", ограниченность её употребления. В большинстве справочных изданий лексика этой тематической группы имела пометы „устар.”, „историзм”, „архаизм” и т.п. (...) русская церковно-религиозная лексика, имеющая многолетнюю историю и давно ставшая своеобразным отражением нравственной основы русской культуры и традиционного сознания россиян, в XX веке неоднократно претерпевала существенные изменения, трансформировалась и переосмысливалась, подверга- 
лась запретам, вытеснялась из употребления и возвращалась вновь" [Шмелькова 2011, 292]. Помимо этого, в словарных толкованиях часто можно было встретить формулировки, пометы типа „иерк.”, „по религиозным верованиям" и т.п. Другими словами, использовались различные способы воздействия на людей посредством отрыва от религиозного языка, подмены, выхолащивания его содержания очень часто при сохранении форм. В итоге, помимо орфографии, которая была тесно связана с деятельностью Церкви, претерпели изменения религиозная лексика и другие уровни религиозного языка. И все эти реформы и манипуляции начали давать ожидаемые результаты, приносить плоды, что неизбежно привело к секуляризации религиозного языка и изменениям в религиозном сознании народных масс, формированию антирелигиозной, атеистической языковой картины мира, сознательному отторжению всего того, что связано с Богом и Церковью.

Приведем еще несколько примеров результатов, следствий манипуляций, связанных с религиозным языком.

Один из примеров, пожалуй, уже ставший энциклопедическим метаморфозы, произошедшие со словом „причастие”.

В „Толковом словаре живого великорусского языка” В.И. Даля в первую очередь делается акцент на описании одного из семи таинств „Св. Причастіе, Евхаристія, Св. Тайнь, Св. Дарь, Тпло-Господнп”, каковым является причастие, затем описывается причастие как форма глагола, а далее опять описываются особенности этимологии слова и образованных от него лексических единиц.

Причаща́mb, причасти́mb кого къ чему, пріобщить, присоединить, сдълать соучастникомъ чего; \| - чего, црк. пріобщать Св. Тайнъ. -сл, стрд. и взв. по смыслу речи; дђлаться общникомъ, участникомъ чего; пріобщаться, принимать Свт.-Тайны, Дары, Причастье. Причаще́нье ср. прича́стье ср. Дちйст. по гл. \| Прича́стье, участье, прикосновенность, сообщенье, сродство, сочувствіе, соотношенье, сопричастіе, связь, зависимость. || Св. Причастіе, Евхаристія, Св. Тайны, Св. Дары, ТЊло-Господнъ̆. \| Грамат. причастье, часть речи, причастная глаголу, въ образб̆ прилагательнаго. Прича́стный чему, прикосновенный, участвующій въ чемъ, близкій, сродный, соучастный, связанный, союзный. Онъ этому дплу не причастенъ. Причастный стихъ или прича́стенъ м. црк. стихъ, поемый на литургіи, во время причащенья Св. Тайнъ священника въ алтарђ̈. Прича́стникъ м. -ница ж. общникъ, участникъ, соучастникъ, сообщникъ, сопричастникъ; принимавшій въ чемъ либо участіе, содъйствовавшій, помогавшій. $\|$ Црк. причащающійся Св. Тайнъ. Нынл много причастниковъ. Прича́ствовать чему, участвовать въ чемъ, быть причастнымъ. Не причаствовалъ я этому дюлу. 
В „Толковом словаре русского языка” под редакцией Д. Н. Ушакова, изданном после описываемых реформ, причастие - это сначала глагольная форма, а затем „Вино и хлеб, употр. при причащении”. О самом таинстве в данных словарных статьях речь не идет.

ПРИЧ'АСТИЕ, причастия, ср. (грам.). Отглагольное имя прилагательное, имеющее форму времени и залога. Поющий - причастие настоящего времени от глагола петь.

I. ПРИЧ'АСТИЕ, причастия, мн. нет, ср. (церк.). 1. Вино и хлеб, употр. при причащении. 2. То же, что причащение (разг.). После причастия.

II. ПРИЧ'АСТИЕ, причастия, мн. нет, ср. (книж. устар.). То же, что причастность. Причастие его к этому делу не установлено.

[Ушаков 1935-1940, т. 2]

Учащиеся средних школ в 1970-1990-х годах XX столетия, спустя 50-60 лет после описываемых реформ, на вопрос „Что такое причастие?”, как правило, сначала отвечали, что это „форма глагола”, и только потом уже некоторые из них могли вспомнить, что „это имеет какое-то отношение к Церкви". И в этом нет ничего удивительного. В „Большом толковом словаре русского языка” под редакцией С. А. Кузнецова, который был издан после перестройки, когда, казалось, что-то уже должно было измениться, поданы два омонима: и первым из них является „форма глагола”, а вторым „обряд причастия” и „Пресный хлеб и вино, олищетворяющие тело и кровь Иисуса Хриcma".

1. ПРИЧАСТИЕ, -я; $\boldsymbol{c p}$. Лингв. Форма глагола, совмещающая в себе признаки глагола (время, залог, вид) и прилагательного (изменение по родам, склонение). Действительное, страдательное $n .<$ Причастный, -ая, -ое. П-ая форма. П. оборот.

2. ПРИЧАСТИЕ, -я; ср. Церк. 1. = Причащение. Обряд причастия. Готовиться $\propto$ причастию. Участвовать в причастии. 2. Пресный хлеб и вино, олицетворяющие тело и кровь Иисуса Христа, используемые во время причащения. Святое $n$. Принять $n$.

[Кузнецов 2000]

„Форма глагола”, „вино”, „хлеб”, „обряд”, „церк.” ... - нужно ли говорить о потенциальных и реальных последствиях манипуляций?

Еще один пример из школьной жизни приблизительно того же периода. В девятом классе общеобразовательной средней школы 15-16летние учащиеся, анализируя „Преступление и наказание” Ф.М. До- 
стоевского, очень часто не могли понять, почему так страдает главный герой, которому удалось расправиться со старухой-процентщицей, о каких духовных исканиях идет речь и зачем идти в полицию доносить на себя, а затем отправляться на каторгу, чтобы очистить свою душу. Ведь можно было просто промолчать. Вполне очевидно, что причина такой трактовки заключалась в том, что то поколение выросло в эпоху тотального атеизма и в другой языковой среде. В их языковой и концептуальной картинах мира не было Бога, а даже если Он и был, то это был пережиток прошлого, не совсем понятный персонаж, как у А. Блока, „в белом венчике из роз”, „с кровавым флагом”, о котором в словарях было написано: „иерк.”, „устар.”, „историзм”, „архаизм”, „по религиозньл верованиям ...”. Поэтому содержание многих изучаемых художественных произведений и их язык для молодежи оставались за семью замками, сами тексты часто оставались только формой, их религиозный язык воспринимался как художественное средство, а „Преступление и наказание” некоторые из них воспринимали как скучный детектив, другими словами: „из купели вместе с водой выплеснули и младенца".

Все перечисленные действия, реформы, мероприятия, распоряжения, направленные на изменение языка и принесшие ожидаемые плоды, - это, по нашему мнению, ни что иное, как одна из форм речевого воздействия - манипуляция (Не персуазия!), жертвами которой неосознанно стали те, на кого воздействовали, кем манипулировали.

И в то же время, вопреки сложившейся ситуации, религиозный язык для достаточно узкого круга верующих людей и священнослужителей оставался средством персуазии (не манипуляции), а спустя почти 70 лет после описываемых событий начался новый виток его эволюции. В повседневную жизнь верующих, и не только верующих, начали возвращаться незаслуженно забытые слова и их значения, а ту же самую классическую литературу начали преподавать по-новому.

Обращение к текстам духовных проповедей второй половины XX - начала XXI веков позволяет заметить, что в них представлены разнообразные языковые средства - теонемы, выполняющие персуазивные задачи, являющиеся „строительными элементами” антитез, инверсий, метафор, повторов, сравнений, эпитетов и других средств выразительности, употребляемых в религиозном языке с целью выполнения персуазивной функции. В качестве примера приведем выдержки из православных текстов. Фрагменты проповедей архимандрита Иоанна (Крестьянкина), архимандрита Антония (Сурожского), о. Артемия (Владимирова) цитируются по работе О.А. Прохватиловой [2011, 7-13], 
а фрагменты проповеди Святителя Луки - по работе Г.П. Гадомской [2020, 376-378].

1. Метафоры:

Круг иерковного богослужебного чина/ снова подвел нас/ $\kappa$ вратам/ Великого поста/ (...) мь начнем/ беседу нашу/ сегодняшнюю/ с первых шагов/ с обращения $к$ Богу/ начнем/ с Сапфея мытаря/ ибо подобно ему/ мало ли людей/ еще блуждают/ по распутьям жизни/ во мгле житейского тумана/ озираясь туда и сюда/ водимье призрачньлми ... иелями/ вдали от Бога/... [Проповедь об Иоанне Златоусте архимандрита Иоанна (Крестьянкина)]. Грубость мужского сердиа/ восполняется/ нежностью и иистотой/ сердиа жень/ ибо сердие женщины/ гораздо тоньше/ способнее/ $\kappa$ духовной любви/ (...) мужчина и женщина/ должны стать в браке/ одним телом/ и одной душой [Проповедь о семье и воспитании детей Святителя Луки (Войно-Ясенецкого)].

\section{2. Эпитеты:}

...и святая Церковь/ воздавая молитвенную память, праведникам/ ветхозаветным/ жившим/ ожиданием/ Рождества Христова/ и праведникам/ жившим/ от исполнения обетования/ и ныне живуших верою зовет/ придите вси/ Христово Рождество/ верою празднуем/... [Проповедь о молитве Господней архимандрита Антония (Сурожского)]. Вознесение/ на недосягаемую высоту/ святости брачных уз/ есть/ самая совершенная/ степень любви/ самая высокая/ и самая святая/ любовь $к$ Богу [Проповедь о семье и воспитании детей Святителя Луки (Войно-Ясенецкого)].

3. Сравнения:

Как волки/ на пастьря Церкви/ собрались языческие философы/ и готовы уже были устремиться/ на это простое сердче/ не знавшее/ языческой премудрости/... [Слово о. Артемия (Владимирова) в день святителя Спиридона Тримифунтского]. Господь/ возглавляет Церковь/ как голова/ венчает наше тело/ (...) так/ должнь мужья/ любить своих жён, как свои тела; так каждый из вас да любит свою жену, как самого себя [Проповедь о семье и воспитании детей Святителя Луки (Войно-Ясенецкого)].

4. Инверсии:

Воскресение Христово/ открыло людям/ врата неба/ избавило мир от духовной погибели/ даровало им/ жизнь/ вечную/... [Слово 
Патриарха Московского и Всея Руси Алексия II на Пасхальной вечере в храме Христа Спасителя]. Если не воспитьвваете/ детей своих/ в нравах христианских/ (...) не думайте/ ито этим запрещается/ вам уиить детей ваших/ (...) мь// членьи тела Его/ от плоти Его/ и от костей Его/ в Нем/ жизнь наша [Проповедь о семье и воспитании детей Святителя Луки (Войно-Ясенецкого)].

\section{5. Антитезы:}

...и здесь/ и Сапфей мытарь/ славный/ неправедныл богатством/ и униженный/ всеобщим презрением/ и от богатьх/ и от бедньх/ (...) Сокрушайтесь/ плачьте/ и рьъдайте/ смех ваш/ уже обратился в плач/ и радость/ в печаль/... [Проповедь об Иоанне Златоусте архимандрита Иоанна (Крестьянкина)]. Того/ почитали несчастныл/ кто знает всё/ и не знает Бога/ того блаженным/ кто знает Бога/ хотя бы/ и не знал/ ничего другого/ (...) будут ли/ чисть и иеломудреннь/ дочери ваши/ если вы сами/ подаёте им пример прелюбодеяний [Проповедь о семье и воспитании детей Святителя Луки (Войно-Ясенецкого)].

\section{6. Повторы:}

Но сила/ Духа Святаго/ пленила их сердие/ и из волков/ они стали/ овцами/ овцами доброго пастыря/ пастыря/ имя которому/ Cnиридон/ который пас/ не только овец духовных/ но и в простоте своего сердиа/ и обыиных/ обычных/ земных/ животных овеи/... [Слово о. Артемия (Владимирова) в день святителя Спиридона Тримифунтского]. От века/ и до века/ (...) разве вы станете/ работать за него/ разве не разгневаетесь на нерадивого слугу/ (...) тяжкий/ тяжкий/ ответ/ дадите перед Богом [Проповедь о семье и воспитании детей Святителя Луки (Войно-Ясенецкого)].

Как отмечает О.А. Прохватилова, специфика использования в современной православной проповеди выразительных средств обусловлена их функциональной многоплановостью. С одной стороны, они способствуют созданию образности, экспрессивности, выразительности речи пастыря, с другой - всегда связаны с содержанием, формируют и воплощают его [Прохватилова 2011, 12]. Другими словами, речь идет о персуазии и формировании соответствующей картины мира.

В чем же отличие выразительных средств современного религиозного языка от языка светского? За счет чего религиозный язык как средство персуазии позволяет убеждать, наставлять на путь истинный? На наш взгляд, наличие перечисленных возможностей объясня- 
ется его насыщенностью теонемами на всех языковых ярусах, наличие и особая организация которых способствует созданию эффективных средств выразительности религиозных текстов и формированию адекватной религиозной языковой и концептуальной картины мира носителей языка.

\section{Выводы}

Проделанная работа позволила сделать выводы. Персуазия и манипуляция - это две полярные, „разнозарядные” формы речевого воздействия. Первая направлена на принятие реципиентом рациональной аргументации адресанта, уговаривание, усиливающее рациональную аргументацию и воздействующее на рациональную сферу реципиента. Вторая же нацелена на то, чтобы вызвать определенное отношение/действие адресата именно в интересах отправителя сообщения, не обязательно совпадающее с интересами адресата. При этом получатель информации часто не распознает эту коммуникативную установку на управление его поведением или мнением.

Основным средством передачи религиозных знаний является религиозный язык, который может служить как инструментом, орудием персуазии, средством воздействия на верующих с целью формирования адекватной, истинной религиозной картины мира, так и использоваться с целью осуществления для различного рода манипуляций.

Рассуждая о религиозном языке как инструменте речевого воздействия, используемого с целью формирования религиозной картины миpa, не следует забывать о теонемах - единицах, служащих для передачи религиозного содержания и представленных на всех уровнях его системы. Как подтверждают многочисленные примеры из художественных текстов и словарей русского языка, в индивидуальной речи и в различных контекстах теонемы, сохраняя внешнюю форму, могут приобретать иное, нерелигиозное, содержание. Поэтому в разряд теонем могут переходить и элементы светского языка при условии их использования для формирования религиозной картины мира.

\section{Литература}

Blok A. A., 1999, Polnoe sobranie sochinenij i pisem v 20-ti tomax. Tom V., Moskva. [Блок А. А., 1999, Полное собрание сочинений и писем в 20-ти томах. Том V., Москва]. 
Chernyavskaya V. E., 2014, Diskurs vlasti i vlast' diskursa: problemy' rechevogo vozdejstviya, Moskva. [Чернявская В. Е., 2014, Дискурс власти и власть дискурса: проблемь речевого воздействия, Москва.]

Dal' V. I., 1880-1882, Tolkovyj slovar' živogo velikorusskogo âzyka: T. 1-4 / [sočinenie] Vladimira Dalâ. 2-e izdanie, ispravlennoe i značitel'no umnožennoe po rukopisi avtora, Sankt-Peterburg; Moskva. [Даль В. И., 1880-1882, Толковый словарь живого великорусского языка: Т. 1-4 / [сочинение] Владимира Даля. 2-е издание, исправленное и значительно умноженное по рукописи автора, Санкт-Петербург; Москва].

Gadomskaya G.P., 2020, Sem'ya $i$ vospitanie detej v religioznom diskurse Arxiepiskopa simferopol'skogo i kry'mskogo Luki, „Stylistyka” XXIX, s. 365-383. [Гадомская Г.П., 2020, Семья и воспитание детей в религиозном дискурсе Aрхиепископа симферопольского и крымского Луки, „Stylistyka” XXIX, c. 365-383.

Gadomskij A.K., 2006, Religioznyj yazyk ili stil': popytka sistematizacii terminologii teolingvistiki, „Ucheny'e zapiski Tavricheskogo nacional'nogo universiteta imeni V.I. Vernadskogo", t. 19 (58), № 2: Filologiya, Simferopol', s. 186-193. [Гадомский А.K., 2006, Религиозный язык или стиль: попытка систематизачии терминологии теолингвистики, „Ученые записки Таврического национального университета имени В.И. Вернадского", т. 19 (58), № 2: Филология, Симферополь, с. 186-193.]

Golodnov A.V., 2003, Lingvopragmaticheskie osobennosti persuazivnoj kommunikacii (na primere sovremennoj nemeczkoyazy'chnoj reklamy'): avtoref. diss. ... k. filol. nauk, Sankt-Peterburg. [Голоднов A.В., 2003, Лингвопрагматические особенности персуазивной коммуникации (на примере современной немецкоязычной рекламы): автореф. дисс. ... к. филол. наук, Санкт-Петербург.]

Goncharova E.A., 2003, Eshhyo raz o stile kak ob"ekte sovremennogo yazy'koznaniya, [v:] Tekst - Diskurs - Stil', Sankt-Peterburg, s. 9-23. [Гончарова Е.А., 2003, Ешё раз о стиле как объекте современного языкознания, [в:] Текст - Дискурс - Стиль, Санкт-Петербург, с. 9-23].

Iczkovich T.V., 2007, Pravoslavnaya propoved' kak vid teksta: avtoreferat dis. ... kand. filol. nauk, Ekaterinburg. [Ицкович Т.В., 2007, Православная проповедь как вид текста: автореферат дис. ... канд. филол. наук, Екатеринбург.]

Iglaeva G.O., 2014, Ob istorii sozdaniya „Tolkovogo slovarya russkogo yazy'ka” pod redakciej D.N. Ushakova, ,Textus”, t. 14, s. 95-103. [Иглаева Г.О., 2014, Об истории создания „Толкового словаря русского языка” под редакцией Д.Н. Уиакова, „Textus", т. 14, с. 95-103.]

Issers O. S., 2009, Rechevoe vozdejstvie, Moskva. [Исcерс О. С., 2009, Речевое воздействие, Москва.]

Kładoczny P., 2004, Proroctwa chrześcijańskie jako gatunek mowy na tle innych gatunków profetycznych, Zielona Góra. 
Kuzneczov S. A. (gl. red.), 1988, Bol'shoj tolkovy'j slovar' russkogo yazy'ka, SanktPeterburg. [Кузнецов С. А. (гл. ред.), 1988, Большой толковый словарь русского языка, Санкт-Петербург.]

Panov M.V., 1968, Russkij yazy'k $i$ sovetskoe obshhestvo. Leksika sovremennogo russkogo literaturnogo yazy'ka, Moskva. [Панов М.В., 1968, Русский язык и советское общество. Лексика современного русского литературного языка, Москва.]

Postanovleniya sovnshhaniya po voprosu ob uproshhenii russkago pravopisaniya, prinyaty'ya 11 maya 1917 g., Sankt-Peterburg, s. 1-8. [Постановления совпщанія по вопросу объ упрощеніи русскаго правописанія, принятыя 11 мая 1917 г., Санкт-Петербург, с. 1-8.]

Proxvatilova O.A., 2011, Vyrazitel'ny'e sredstva sovremennoj pravoslavnoj propovedi, „Vestnik Volgogradskogo gosudarstvennogo universiteta”, seriya 2: Yazy'koznanie, № 1 (13), s. 7-13. [Прохватилова О.А., 2011, Выразительнье средства современной православной проповеди, „Вестник Волгоградского государственного университета", серия 2: Языкознание, № 1 (13), c. $7-13$.

Shelestyuk E. V., 2008, Tekstovy'e kategorii argumentativnosti, suggestivnosti $\mathrm{i}$ imperativnosti kak otrazhenie sposobov rechevogo vozdejstviya, „Vestnik Chelyabinskogo gosudarstvennogo universiteta”, vy'p. 26, № 30 (131), seriya „Filologiya. Iskusstvovedenie”, s. 170-175. [Шелестюк Е. В., 2008, Текстовые категории аргументативности, суггестивности и императивности как отражение способов речевого воздействия, „Вестник Челябинского государственного университета", вып. 26, № 30 (131), серия „Филология. Искусствоведение”, с. 170-175.]

Shmel'kova V.V., 2011, K voprosu o leksicheskix izmeneniyax $v$ russkom yazy'ke poslerevolyucionnogo perioda, „Izvestiya PGPU im. V.G. Belinskogo. Gumanitarny'e nauki", № 23, s. 290-292. [Шмелькова B.В., 2011, K вопросу о лексических изменениях в русском языке послереволючионного перио$\partial a$, „Известия ПГПУ им. В.Г. Белинского. Гуманитарные науки”, № 23, c. 290-292.]

Svyatitel' Luka (V. F. Vojno-Yaseneczkij), 2017, O sem'e i vospitanii detej, Moskva. [Святитель Лука (В. Ф. Войно-Ясенецкий), 2017, О семье и воспитании детей, Москва.]

Ušakov D. N. (red.), 1935-1940, Tolkovyj slovar' russkogo âzyka: T. 1-4, Moskva. [Ушаков Д. Н. (ред.), 1935-1940, Толковый словарь русского языка: Т. 1-4, Москва].

Xuty'z I.P., Kolchevskaya V.A., 2018, Persuazivnost': specifika fenomena v nekotory'x tipax institucional'nogo diskursa, „Filologicheskie nauki. Voprosy' teorii i praktiki”, № 2 (80), ch. 2, s. 391-394. [Хутыз И.П., Колчевская В.А., 2018, Персуазивность: специфика феномена в некоторых типах институционального дискурса, „Филологические науки. Вопросы теории и практики", № 2(80), ч. 2, с. 391-394.] 
Bajerowa I., Puzynina J., 2000, Art. Jezzyk religijny. Aspekt filologiczny, [w:] Encyklopedia katolicka, Lublin, t.8, s. 19-20.

Barańczak S., 1983, Czytelnik ubezwłasnowolniony, Paryż.

Bralczyk J., 2004, Język na sprzedad, Gdańsk.

Chaiken S., Liberman A., Eagly A., 1989, Heuristic and systematic Information 218 Processing within and beyond the Persuasion Context, [in:] Unintended Thought, New York, p. 212-252.

Gansel, Chr., 2011, Textsortenlinguistik, Göttingen.

Greule A., Kucharska-Dreiß E., Makuchowska M., 2005, Neure Forszungen zur Sakralsprache im deutsch-polnische Verglejch. Erträge - Tendenzen - Aufgaben, „Heiliger Dienst”, Heft 2, s. 73-91.

Hoffmann M., Kessler C., 1998, Persuasion als Forschungsgegenstand: Vorbemerkungen zum Thema, [in:] Beiträge zur Persuasionsforschung: unter besonderer Berücksichtigung textlinguistischer und stilistischer Aspekte, Frankfurt am M., s. 7-12.

Hovland C.J., Janis I.L., Kelley H.H., 1953, Communication and Persuasion: Psychological Studies of Opinion Change, New Haven.

Kosta P., 1996, Zur semantischen Struktur und illokutionären Kraft persuasiver Sprechakte, [In:] Slawistische Linguistik 1995. Referate des XXI. Konstanzer Slawistischen Arbeitstreffens, Mainz 26-29.9.1995, München, s. 201-226.

Kucharska-Dreiß E., 2004, Teolingwistyka - próba popularyzacji terminu, [w:] S. Mikołajczak, T. Węcławski (red.), Język religijny dawniej i dziś. Materiały z konferencji, Gniezno 15-17 kwietnia 2002, Poznań, s. 23-30.

Lewandowski T., 1994, Linguistisches Wörterbuch, Heidelberg; Wiesbaden, Band I-III.

Mann E., 1999, Persuasive Sprechhandlungen in Alltagsdialogen des Russischen, unter besonderer Berücksichtigung ihrer Handlungsbedingungen: Inauguraldissertation zur Erlangung des Grades eines Doktors der Philosophie, Potsdam.

Moilanen M., 1996, Zur kommunikativ-funktionalen Interpretation von persuasiven monologischen Texten, [in:] Motsch, W. (Hg.), Ebenen der Textstruktur: sprachliche und kommunikative Prinzipien, Tübingen, s. 165-188.

Petty R.E., Cacioppo J.T., 1986, Communication and Persuasion. Central and Peripheral Routs to Attitude Change, New York.

Sandig B., 1996, Bewerten in (Autowerbe-)Texten, [in:] Zeitschrift für Germanistik. Neu Folge, VI, 2/1996, s. 272-292.

Zdunkiewicz D., 1991, Jezykowe środki perswazji w homiliach (na przykładzie tekstów Jana Pawta II), Kraków. 


\section{PERSUASIA, MANIPULATION, AND RELIGIOUS LANGUAGE}

\section{ABSTRACT}

Key words: theolinguistics, religious language, speech influence, persuasia, manipulation

This article is an attempt at a theolinguistic description of such concepts as manipulation, persuasia, and religious language. The author focuses primarily on the theoretical aspect of the stated problem.

In the first part of the work, such concepts as manipulation, persuasia and speech influence are analyzed. Their hierarchy is being organized and it is concluded that persuasia and manipulation, when considered in "pure form" is the polar form of speech influence, different in means of achieving the goal: if persuasia is an open speech influence, suggesting a deliberate choice by the recipient, speech influence with the sign "+", then the manipulation is speech influence, often using hidden mechanisms with the aim of achieving a result, do not necessarily coincident with the interests of the recipient, speech influence with the sign "-_".

The second part of the work describes the religious language and its functions. Special attention is paid to the instrumental function - the function of using language as a means to achieve certain goals. Attention is drawn to the fact that the use of the form and content of religious language not only opens the way for various kinds of manipulations with language and with the help of language, but also for persuasia: the transfer of relevant knowledge, the formation of beliefs, ideas about true values. 